\title{
10. Interrogating corporate philanthropy in education: the case of Nigeria
}

\section{Inyang Udo-Umoren}

\section{INTRODUCTION}

Upon independence from colonial rule, education held promise and hopes for the African continent. Yet, the rapid pace at which the sector grew did not sustain dreams of more schools, teachers, learners and innovations. Consequently, the twentieth century has seen schools in many countries facing conditions which have been summarised by Samoff and Carrol (2013) as having 'no teachers' guides, no textbooks, not even chairs' (p. 403). As of 2014, Nigeria, the largest country in Africa by population size, had over 10 million of the 57 million out-of-school children globally (UNESCO, 2014). While its out-of-school population increased by 42 per cent between 1999 and 2010, Ethiopia, the second most populous nation in Sub-Saharan Africa, had a three-quarters reduction in its out-of-school population (UNESCO, 2014).

A number of demand and supply factors affect access to basic education in Nigeria and funding features across the spectrum. From a demand perspective, it is arguable that household income is strongly associated with enrolment; therefore, high direct costs of education constitute a deterrent for children from the poorest backgrounds, especially in the northern region (World Bank, 2008). Although basic education is free, in principle, some direct costs such as expenditures on books, uniforms and other educational materials are passed onto households, including various forms of charges that may as well serve as indirect tuition fees. Over 60 per cent of the Nigerian population is poor (British Broadcasting Corporation, 2012) and unable to afford these costs, particularly in rural areas.

Supply side factors have generally been poor. The World Bank (2008) reported that the quality of education is weak, as indicated by inadequate inputs such as textbooks and instructional materials. Also, there is a shortage of well-maintained educational and sanitary facilities as well as 
a shortage of qualified staff (World Bank, 2008). Nigeria was estimated to have the largest gap in recruiting additional primary teachers with a need for 212,000 teachers between 2011 and 2015 (UNESCO, 2014).

Insufficient state funding and a declining trend in foreign aid presupposes a need to explore other means of financing education in developing countries. Alongside several developing countries experiencing financial constraints, Nigeria has historically been dependent on aid from bilateral and multilateral donors for educational development, among other sectors. However, even though the country has the highest number of out-of-school children in Sub-Saharan Africa, it is not among the top 10 recipients of aid.

The private sector is increasingly being targeted as an alternative source of finance. Burnett and Bermingham (2010) point out that an important source of financing is still often neglected or excluded from the current debate: the country's domestic resources. These domestic resources include private foreign direct investments and philanthropic donations from private philanthropists and foundations. Private philanthropic resources are a support to bridge gaps in national and donor governments' commitments to achieving universal, quality education for all (Srivastava \& Oh, 2010; van Fleet, 2012). Given the prevailing financial circumstances in some developing countries, and particularly Nigeria in this instance, corporate philanthropy, through corporate social responsibility (CSR) initiatives, presents an alternative finance model worth exploring.

\section{CORPORATE PHILANTHROPY AND CORPORATE SOCIAL RESPONSIBILITY}

Businesses contribute their resources to social services like education through corporate social engagement activities, but the terms and definitions are often unclear and contradictory (Garriga \& Melé, 2004; Husted $\&$ Allen, 2006). Business scholars have argued that businesses have four responsibilities to society-economic, legal, ethical and philanthropic (Carroll, 1979, 1991; Matten \& Moon, 2008). Ethical and philanthropic responsibilities are less self-explanatory than the former two. Conducting business in an ethical manner represents ethical responsibilities and philanthropic responsibilities which can be defined as 'those corporate actions that are in response to society's expectation that business be a good corporate citizen. These include actively engaging in acts or programmes to promote human welfare or good will' (Carroll, 1991, p. 42). Given the consideration that ethical and philanthropic responsibilities can be classified as those responsibilities 'beyond' the economic and legal responsibilities of 
a corporation, Carroll and Shabana (2010) suggest that these two may well be understood as the essence of CSR as they are the elements considered in the debate of what constitutes the nature and extent of additional corporate obligations to the society. Although CSR can be classified as an 'umbrella' term for the varied responsibilities that businesses have within society, including philanthropy, the term CSR initiatives is also used to characterise corporate philanthropy.

Historically, philanthropy has been viewed as activities undertaken for purely altruistic reasons where no returns/benefits are expected. However, within the business context, altruistic motivations are debatable. Traditionally defined as 'goodness' and a 'habit of doing good' (Sulek, 2010, p. 195), philanthropy has evolved over the years to be conceptualised as donation of money for good causes (Organisation for Economic Co-Operation and Development [OECD], 2003), which Srivastava and Oh (2010) noted places emphasis on the donation of money, not on the classical benevolent acts but through organised structures.

\section{MODES OF CORPORATE PHILANTHROPY IN EDUCATION}

CSR investments in education are largely considered philanthropic, although the convergence of business interests and philanthropy appears to blur the lines of engagement and CSR initiatives cover a wide range of activities. The modes of private participation in education are conceived to cover instances where the private sector is involved in the provision of education service either through private finance or government finance (Patrinos, Osorio \& Guáqueta, 2009). However, corporate philanthropy as a form of private sector participation is said to fall within the schema where only financial contributions are made, while the provision and delivery of education is left to the state (LaRocque, 2008), as depicted in the Table 10.1. It is worth mentioning that there is really no clear demarcation as some companies are known to be involved in provision of education through their own private (fee-paying) or public (subsidised or free) schools.

\section{Direct Contributions}

Traditionally, corporate contributions have been in the form of donations to support schools either directly or through corporate foundations (Colvin, 2005), with the use of foundations being primarily for tax purposes as companies are allowed to write-off financial profits as corporate giving for charitable purposes (van Fleet, 2012). Some corporations make 
Table 10.1 Financing versus provision of government services

\begin{tabular}{lll}
\hline & Private Provision & Public Provision \\
\hline $\begin{array}{l}\text { Private } \\
\text { Financing }\end{array}$ & $\begin{array}{l}\text { Traditional fee-paying private } \\
\text { schools }\end{array}$ & $\begin{array}{l}\text { Private philanthropic ventures } \\
\text { Tuition fees and other user fees } \\
\text { in public schools } \\
\text { Adopt-a-school programmes }\end{array}$ \\
$\begin{array}{ll}\text { Public } \\
\text { Financing }\end{array}$ & $\begin{array}{l}\text { Contract schools } \\
\text { Charter schools } \\
\text { Voucher programmes } \\
\end{array}$ & \\
& $\begin{array}{l}\text { Private school subsidy } \\
\text { programmes }\end{array}$ & \\
\hline
\end{tabular}

Note: Based on LaRocque (2008).

cash donations through grant schemes while in-kind contributions may consist of tangible products or services. With the education sector in some countries experiencing issues of access and quality, some companies are extending into provision of private education but on a non-profit basis. Van Fleet (2012) found that the projected annual U.S. corporate contribution to education in developing countries is a few dollars short of USD 500 million dollars, placing U.S. companies, on aggregate, as the seventh largest donor group to education in developing countries. However, cash donations constitute only 70 per cent of that amount, with the remaining 30 per cent being in-kind donations and professional services.

Adopt-a-school programmes are also popular with companies and often involve corporations assisting the poorest public schools with cash and in-kind products as a means of complementing government funding. However, there are instances where corporations run non-profit schools as part of their CSR initiatives. For example, Bradesco Bank in Brazil, through its corporate foundation (a non-profit entity) that was founded in 1956, currently maintains 40 schools in underprivileged regions across Brazil and is considered the largest private education provider in the country (Bhanji, 2008; Bradesco Bank, 2014). As of 2006, the World Economic Forum (WEF) reported that at least half a million children had been through the schools and the dropout rates were lower than three per cent (as cited in Bhanji, 2008).

\section{Partnerships}

Ordinarily, companies partner with non-profit organisations or charities to distribute their social budget (Valor, 2007), but in recent years, collaboration 
with various actors has become prominent. Given the growing focus on the achievement of education and development goals, corporations are now working with states and multilateral agencies. One current argument is that governments need to work with a range of actors representing the private sector - corporations, civil society, independent experts and communities, termed public-private partnerships (PPPs). A PPP can be defined as 'a model of development cooperation in which actors from the private sector (private corporations, corporate foundations, groups or associations of business) and the public sector (Ministry, local authorities) pool together complementary expertise and resources to achieve development goals' (Genevois, 2010, p. 110). Another level of partnership which appears to be preferred by the WEF is called multi-stakeholder partnerships for education (MSPEs), and their appeal lies in the broader coalition of partners and stakeholders beyond public and private sectors. Within the context of PPP, engagement may be formal or contractual with the state determining the scope, priorities, outputs and performance indices (LaRocque, 2008); however, a collaborative and participatory approach to policy-making and implementation on broader social issues is adopted for multi-stakeholder partnerships, hence their frequent usage in relation to the achievement of the Sustainable Development Goals.

\section{CORPORATE PHILANTHROPY IN EDUCATION IN NIGERIA}

CSR has been predominantly shaped by the West, and its origin in Nigeria is traceable to the multinational companies (MNCs) in operation within the oil sector. MNCs like Shell Oil have been operating in Nigeria even before its independence from colonial rule in 1960, and as part of its community development initiatives, it has built classrooms, awarded scholarships and provided stipends for teachers willing to teach in rural areas, among others. A number of researchers have argued that the CSR practices of MNCs in the oil sector serve as a means of protecting business interests that may be jeopardised by the effects of their extraction activities on the communities where they operate (Akpan, 2006; Amaeshi, Adi, Ogbechie \& Amao, 2006).

With the growing influence of globalisation, indigenous companies in Nigeria are now claiming to recognise their social responsibilities and, therefore, engage in CSR practices; however, they adopt a philanthropic/ altruistic approach to CSR and often education features as a top priority (Amaeshi et al., 2006; Obalola, 2008). This trend was also observed in a survey of 85 companies drawn from six African countries, excluding 
Nigeria (Deutsche Gesellschaft für Technische Zusammenarbeit, 2009). Amaeshi et al. (2006) also found that although the CSR practices of MNCs operating in Nigeria were a reflection of business systems in their home countries, indigenous companies use CSR as a tool for addressing socioeconomic issues.

Indigenous companies in Nigeria identify with the challenges within the education sector in Nigeria, and while some respond on an ad hoc basis, others adopt a more strategic approach by incorporating education into their CSR policies or establishing foundations. Education is named as a priority philanthropic activity by CSR and managers within the insurance industry (Obalola, 2008) and banking industry (Amaeshi et al., 2006). Although most of the education initiatives run by indigenous firms are done in partnership with the government, often at state or local government levels, participation in global partnerships is growing.

As of 2015, just two indigenous Nigerian companies, Dangote Group and Oando Plc, ${ }^{1}$ were members of the Global Business Coalition for Education (GBC-Education), an organisation that attempts to bring together businesses with the aim of accelerating delivery of quality education globally. While Dangote Group, an industrial conglomerate, is a platinum member of the GBC-Education, Oando Plc is a gold member. The implications of these membership levels indicate their commitment to making significant investments in education using the following components: core assets, thought leadership, CSR and/or strategic philanthropy for platinum members; investments via CSR and/or strategic philanthropy for gold members (Global Business Coalition for Education, 2014). Nigeria is an emerging economy, and there are good economic prospects (AfDB, OECD \& UNDP, 2014); therefore, there also exists the hope that more indigenous companies will also join global partnerships for development, like the GBC-Education.

While indigenous companies in Nigeria and other African countries have been found to consider education a high priority, their contributions do not appear to garner the same attention as activities by MNCs because of differences in the scale of operations. Generally, within business research, there is a relative dearth of literature on CSR practices by African companies (Amaeshi et al., 2006), and it is also notable that literature reviewed for this study is predominantly comprised of research on activities by MNCs and transnational corporations (TNCs) within education

1 These were among the companies in the secondary sample for this study. As explained later, documentary evidence of the CSR practices of these companies is publicly available, and no one at these companies was interviewed. Therefore, anonymity was not a consideration for these. 
(Bhanji, 2008, 2012; Draxler, 2008, 2012; van Fleet, 2012). There may be a presumption that CSR practices are homogeneous, but a common strand observed through cultural and national studies shows that CSR practice is socio-culturally embedded (Amaeshi et al., 2006). Therefore, a need to explore the CSR initiatives of indigenous companies in Nigeria is necessary to understand the current practice and how that may fit within global discourse on achieving educational goals.

\section{CONCEPTUAL FRAMEWORK}

Underlying the argument for participation of the private sector through CSR in education is the question of what the corporations stand to gain by supporting social causes. Figure 10.1 represents the dynamics of corporate engagement and attempts to explain the interaction between the different themes identified in the research literature.

Economic and social motivations are not mutually exclusive but integrative in the backdrop of CSR. The argument for altruistic reasons for CSR is quite weak, as shown in Figure 10.1, but it is apparent that for any meaningful engagement of the corporate sector in social objectives, elements of economic pursuits cannot be left out. Company rationales for engagement may determine the forms and modes of CSR practices. Motivations that border on enhancing visibility are likely to be demonstrated through cash
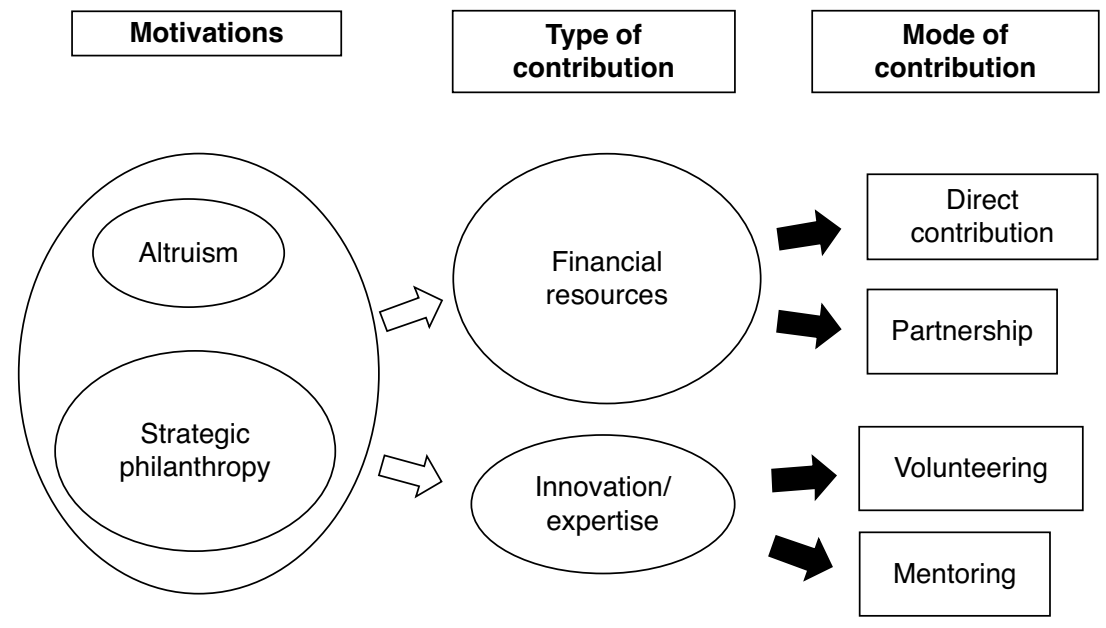

Source: Drawn from Bhanji $(2008,2012)$ and van Fleet (2012).

Figure 10.1 Conceptual framework 
gifts and cause-related marketing initiatives such as sponsorships and inkind donations of products (Porter \& Kramer, 2002). Cash gifts constitute a larger proportion of CSR contributions to developing countries (van Fleet, 2012), as shown in Figure 10.1. On the other hand, engagement through innovation and expertise is likely to indicate intentions to influence policy directions and is often supported by the political economy of the environment. Also, these are often from the angle of provision of education. As captured by Ball (2008), individuals and corporate bodies involved in policy networks and communities attempt to foster a new form of governance through experimentation while 'shaping education mission statements' (Jessop, 2002 as quoted by Ball, 2008, p. 743).

\section{METHODOLOGY}

The key purpose of this study was understanding how the Nigerian corporate sector perceives and contributes towards the educational needs of the country and how, in turn, researchers may understand the place of these contributions in the scheme of global education goals. The scope for the study included understanding the current focus and trend of CSR in education in Nigeria by indigenous organisations and comparing these with foreign-owned organisations; understanding the motivations influencing CSR initiatives in Nigeria; and understanding the implications and limitations of CSR initiatives on financing the Nigerian education sector.

A qualitative approach was adopted for this study as it allows for an investigation of the meaning or nature of experience of 'social life which [is] not amenable to quantitative measurement' (Jupp, 2006, p. 237). As defined by Yin (1994), a case study is 'an empirical inquiry that: investigates a contemporary phenomenon within its real-life context, especially when the boundaries between phenomenon and context are not evident; and... [that] relies on multiple sources of evidence' (cited in Kaarbo \& Beasley, 1999, p. 372). A comparative case study method allows for a "comparison of two or more data points ("cases") obtained through the case study method' (Kaarbo \& Beasley, 1999, p. 372).

Using a comparative study method, two organisations - an indigenous and a foreign-owned organisation - were examined as cases. However, references to other companies operating in Nigeria are made intermittently as a secondary sample. The key focus was not only on the similarities of processes but the nature of differences between the cases and how this may inform the dynamics of CSR initiatives in education. 


\section{Data Requirements and Sources}

Embedded in the definition of case study research by Yin (1994) is a key feature of the method-reliance on multiple sources of data. As part of the research design for this study, primary and secondary sources of data were used-interviews and documentary evidence. The researcher conducted two semi-structured, in-depth interviews via telephone and obtained documentary data from public documents: company annual and $\mathrm{CSR} /$ sustainability reports, press releases, organisation websites and other publications on company CSR activities in Nigeria. The interviews were supported by an interview schedule made up of a list of issues relevant to the study identified from the literature review, and these included motivations of business engagement in corporate philanthropy, criteria for selection of beneficiaries, actual contributions and partnerships. However, by virtue of the semi-structured format, additional questions were asked to probe points raised during the discussions.

Purposive sampling was employed in the selection of the two companies investigated as the central cases. Although the original intention was to include more than two central cases, gaining access and acceptance to participate in the study was difficult. However, the two companies with whom interviews were conducted adequately serve the research purpose of comparing CSR activities between indigenously owned companies and companies with majority foreign ownership. Within the secondary sample of companies drawn upon for further comparison, there is a blend of Nigerian-owned and -run companies and MNCs. Data from the companies chosen guided enquiry into the processes and strategies employed in the design and implementation of education CSR initiatives as well as enabled understanding of the varying motivations for engagement in education CSR projects.

\section{Data Analysis}

Given the exploratory nature of this study, a conceptual framework (see Figure 10.1), built from a review of current literature, served as a theoretical foundation to enable examination and interpretation of the cases. Analysis of the data collected was conducted based on themes that emerged from the data and those earlier identified in the literature. The themes from the literature review, coded through identified clusters of ideas, had been used to build the conceptual framework. The major themes and relationships across elements of CSR practices in education, as captured in the conceptual framework, served as a classification and theory-building mechanism, thus not only allowing for a study of key 
factors and themes identified in the literature but also suggesting presumed relationships among them (Miles \& Hurberman, 1994 as cited in Ravitch \& Riggan, 2012). Consequently, the conceptual framework, consisting of emergent patterns and perceived relationships, served as an ad hoc taxonomy for the analysis of the interviews and other data collected from documentary sources.

\section{Ethical Considerations}

The two central organisations examined in this study are large and significant players within their relevant business sectors; therefore, maintaining the anonymity of the representatives interviewed and the organisations' names is essential. Consequently, pseudonyms representing their generic operating sectors have been used to identify them (Nigerian Financial Institution [NFI] and Consumer Goods Company [CGC]). These have been adopted as measures to protect the privacy of both the interviewees and the companies. Also, some identifying details have been changed where applicable.

\section{Participants' Profiles}

NFI is an institution that was incorporated over 20 years ago and is currently listed on the Nigerian Stock Exchange. It offers both commercial and retail services with over 100 branches spread across Nigeria, other African countries and the United Kingdom. The institution is wholly owned and operated by Nigerians with neither an individual shareholder holding more than five per cent of shares nor a custodian (holding shares for a group of various investors) holding more than 25 per cent.

CGC was incorporated before 1960 and is listed on the Nigerian Stock Exchange. The company operates as a brewer with operating plants and distribution outlets spread across the country. It is a subsidiary of a foreign firm which holds over 50 per cent of its shares.

The secondary sample of companies included in the study are the Dangote Group of companies (parent company of Dangote Foundation), Oando Plc (parent company of Oando Foundation) and Access Bank Plc. The Dangote Group is a manufacturing conglomerate while Oando Plc is an oil and gas firm. Documentary evidence of the CSR practices of these sample companies is publicly available. 


\section{THE PRACTICE OF CSR IN EDUCATION IN NIGERIA}

There are no regulatory requirements for engagement in CSR, its budgetary requirement or allocative modalities among competing social objectives. In Nigeria, the recently reviewed National Policy on Education (2013) section 155(e) states that in demonstration of social responsibility, contractors, consultants and other service providers are to contribute minimum of $1.5 \%$ of contract sum/fees to a Special Education Corporate Social Responsibility Fund (SECSRF) to be established' (p.45). This is a new entry in the policy document as it was not in the 2004 version, and although it signals the recognition of the role of CSR, it is directed mainly at contractors and consultants, not companies. Therefore, it may be presumed that there is no formal national requirement, normative or mandatory, that companies engage in CSR nor is there a minimum spending threshold. While this illustrates that companies in Nigeria are not 'legally' required to spend on CSR initiatives, it is worth noting that the companies with more than 100 employees are mandated to contribute two per cent of their assessable profits to an education trust fund. This fund had initially been intended for all levels of education; however, from 2004, it was converted to an exclusive trust fund for tertiary education, particularly for its capital expenditures.

Amidst several social objectives, education is considered important to national development and, therefore, a prime choice for intervention. The companies recognise that they have a role to play in societal development, and education provides a means of attainment. The NFI interviewee emphasised that 'we thought education is key, because really, if we solve the problem of education, I think that that would by itself solve every other problem' (NFI interview, 2015).

The relevance of education is a shared passion, but the extent of commitment differs across the companies. The companies share resources between education and three or more other social development obligations and that influences how much ends up in educational development projects. Data gathered from the annual report of NFI indicates that about 32 per cent of total CSR spending, which amounted to over NGN 150 million (about USD 400,000), was spent on educational projects. CGC, on the other hand, has a dedicated education trust fund that was established with a capital grant of about NGN 100 million (approximately USD 277,000) about 20 years ago and this serves as the source for its projects; however, information on spending per project is not publicly available. Also, according to its annual reports from 2008 to 2012 and its sustainability report from 2013, Oando Plc specifies that it allocates about one per cent of its 
pre-tax profits to education exclusively which is its only CSR focus area, but no finer details of spending are available (Oando Foundation 2013, 2014). These examples point out that it may not be easily discernible how much funding is actually spent on the CSR programmes and how education actually fares on their scale of preference with competing societal objectives.

Within the education spending, the allocation to different aspects of educational needs leaves room for contemplation. A deconstruction of NFI's spending on education suggests that sports may be considered a key facet in educational development as beneficiaries have been encouraged to attend and complete school through the sports initiative, thus improving enrolment. The sports initiative is undertaken in public schools. The next top priority for NFI is expenditure on public schools through adopt-a-school initiatives. Private schools have also been recipients of CSR funding from NFI. The composition of the expenditure may raise another question - was it merely a cash donation, an investment in infrastructural development or investment in information and communication technology (ICT) equipment? For CGC, the primary use of funds appears to be infrastructural development of primary and secondary schools and often constitutes over 50 per cent of total spending on education considering available records for 2010 and 2011. The types of investment undertaken by the companies may serve as indications of their motivations. Some of these motivations will be highlighted in the next section.

\section{Rationale for Performing CSR Initiatives in Education}

The engagement of companies in education CSR initiatives is often predicated on various motives. This section outlines some of the motivations for the Nigerian companies investigated in this study.

\section{Filling the governance gap}

Initiatives undertaken demonstrate a recognition of the gaps in the governance structure of the country. The companies recognise that the government is unable to adequately serve the educational interests of the populace. The contributions are considered because a 'need' has been identified as put forward by the NFI interviewee (2015): 'It's basically about the need of the society which we want to address'.

The same view was expressed by the CGC interviewee but with more emphasis on the state of education infrastructural development and governance. In 2014, on its website (http://www.oandofoundation.org/), Oando Foundation goes further in capturing the position with direct preference for education by indicating that its decision to focus on the 
education sector was born from the realisation that basic education in Nigeria needs support and intervention from the private sector. This indicates that government resources are no longer sufficient to cover the educational needs of the teeming population. However, these approaches to filling the governance gap, evidenced by failure to meet commitments to achieving universal, quality education for all (Srivastava \& Oh, 2010; van Fleet, 2012), fall short of that earlier identified in literature. Contributions involving innovation and expertise either individually or through policy networks or communities are the main avenues of influencing governance structures (see Ball, 2008) but are not evident in the activities of these companies.

\section{Brand and reputation building}

In the short run, some of the benefits of engaging in education CSR can be captured with image branding. Companies like to be associated with good deeds in society. Putting it lightly, the NFI interviewee noted that education CSR initiatives '[have] given so much endearment' (NFI interview, 2015), while the CGC interviewee asserted that 'it helps enhance your reputation and it gives you goodwill. The immediate one is goodwill. Goodwill and reputation building basically' (CGC interview, 2015).

Brand recognition requires visibility and, therefore, depending on the type of contribution, elements that represent the company are used - brand colours are often used for buildings or some form of insignia (a signpost or wall-writing) and branded notebooks. Brand visibility is often better captured in physical infrastructural development and often presented on company websites and reports.

\section{Improving competitive context}

A long-term rationale for investing in education CSR, though subtle, is the attempt to improve a company's competitive context. According to Porter and Kramer (2002), this involves 'improving the quality of the business environment in the location or locations of operations' and emphasises the alignment of corporate giving with long-term business prospects (p. 6). Hence, it relates to creating potential markets or addressing potential business constraints. The NFI interviewee mentioned that although the institution had created a financial product targeted at the age range for primary and secondary school students, the product has not been thriving; however, there is an expectation that information on the product will spread through the publicity garnered from the CSR initiatives in schools. Also, the NFI interviewee admits, hopefully, that there is a likelihood that the students may be 'the ones that will grow and become the customers of the company invariably. So, I think, even now, we are not seeing the direct 
returns, that I think in the long run will make the company sustainable' (NFI interview, 2015).

Additionally, improving the context through education also implies contributions to workforce development as a means of addressing potential business constraints in the supply of skilled employees. The CGC interviewee pointed out that 'maybe, more of a long-term is that, you never can tell, you might impact the life of somebody that might even come to work for you in the future. So, it's like talent development as well' (CGC interview, 2015).

Overall, business sustainability appears to be the long-term benefit when considering the pool of future customers and workforce built through increased access to education facilitated by the CSR initiatives of today.

\section{Types of Education CSR Initiatives}

The common form of contributions from the companies is financial resources. Cash donations or the provision of funds for products and development projects are largely practised by the companies. Predominant amongst these donations is schooling infrastructure-construction or renovation of classrooms, libraries, laboratories, sanitation facilities, and so on and provision of furniture and basic amenities such as electricity and water. These areas appear to be the key focus areas for CGC as they constitute a large proportion of its spending. The NFI interviewee also emphasised the belief that a good learning environment is essential, hence the reason this is part of its adopt-a-school package. Beyond the contributions that are part of the adoption package, an implication worth highlighting is the duration of the commitment, and although the CGC interviewee stressed that the adoption model is not employed by the company, the potential to revisit the schools bears a similarity with characteristics of the model.

How long an adoption scheme lasts and the scope differs amongst the companies. The companies that use the adoption model apply different dynamics to the approach, in terms of how long the schools are adopted, how the development projects are spread across the period and how many schools are adopted over time. NFI first adopted two primary schools in 2004 when it started the initiative, but as of 2014, according to the interviewee, six schools including primary schools and secondary schools had been adopted for life with plans to increase the number of adopted schools (NFI interview, 2015). By contrast, employees of Access Bank Plc had adopted a school in 2009 to last for three years, with different donations such as provision/renovation of classrooms, restrooms, computers, water supply and electricity spread across the period (Access Bank Plc, 2009). 
While the spread of activities over a time span is similar with NFI, the CGC interviewee pointed out that the company only meets the infrastructural needs of a school at a particular point in time (CGC interview, 2015). However, Oando Plc started running the adoption model in 2007 as part of its CSR strategy before setting up its foundation in 2011. While it had 28 adopted schools as of 2011, its reach through its foundation (Oando Foundation) had expanded to 58 schools (primary schools) across 23 states with an ongoing target of reaching 100 schools by the end of 2015, and it was presumed that these schools would remain adopted long-term. While for Oando Plc and NFI the initiative is a direct contribution from the foundation or company, for Access Bank Plc, also an indigenous company, adopting schools or investments in infrastructural development projects appears to be largely undertaken as part of employee volunteering schemes.

Scholarships represent another significant financial investment in education and are intended to facilitate completion and transition between levels of education. The scholarships often cover tuition, uniforms, books and other expenses; however, while NFI runs its scholarships for students of its adopted secondary and primary schools, CGC runs its scholarship schemes largely for tertiary levels. The NFI scholarships are offered for the best performing student in every grade level, except the last senior secondary grade. Consequently, it supports transition from primary to secondary school, but the interviewee emphasised that the candidates have to maintain the performance levels to be eligible for the award as they progress through the levels (NFI interview, 2015). Given that the scholarships are merit-based and only available for one student per grade, their potential effects may be minimal. Being merit-based implies that the student best at an assessment will be selected and the likelihood that the student is from a richer household with better access to educational materials is unaccounted for; therefore, this could contribute to efficiency losses in the education system.

The issue of education quality borders largely on quality of teachers and the learning process; however, there are indications that teacher training and development are not considered educational priorities by these companies. There are no accounts of CGC carrying out projects to support teacher development, even under its incorporated education trust fund. The NFI interviewee listed teacher quality as one of the gaps that the company makes efforts to address, particularly in its adopted schools (NFI interview, 2015). Over the years, the company has enlisted the support of the British Council to deliver training to some teachers. However, NFI sponsors only one or two trainings in a year and the sessions accept an average of 20 teachers. The effect of this is likely to feel like a drop in the 
ocean considering that Nigeria has the greatest need for quality teachers. Other areas of financial contribution, more popular than teacher development, are contributions to support competitions - essay, creative arts and writing and sports as well as conferences, especially for universities.

The companies also contribute to educational development through sharing knowledge and expertise with the students. Educational support programmes run by the companies that allow for the use of expertise include career counselling and mentoring schemes which are often supported by employee volunteers. In 2011, CGC invested about NGN 8 million (approximately USD 22,000) in a career guidance initiative targeted at senior secondary school students. Career talks were held to provide information on career choices and key considerations to guide decision making.

\section{Mode of Contributions}

Generally, given the penchant for cash donations, the common conduit for donations is non-governmental organisations; however, with respect to some projects, engagement with government and international agencies may be deemed necessary. Given the fact that most of the schools that are recipients of direct contributions are public schools, the NFI interviewee emphasised that "partnering with the government is a key thing for us. In any of our education projects, we partner with the ministry of education, whatever state we are in. .' (NFI interview, 2015). As a benefit of the partnership, the NFI interviewee specified that a transfer of expertise ensues when all parties are involved. This relationship with government is reflected in the following quote: 'We partner with them, so that we can teach them how to do things the proper way. It helps for smooth running of the project, that's one, but then for it to be sustainable, we should all be in' (NFI interview, 2015). The interviewee further cited the communication process with government representatives, with reference to the adopt-a-school initiative: 'We write to them, the letters; we deliberate; we agree and then we sign a memorandum of understanding. These show what we intend to do, and we would always run what we have to do by them' (NFI interview, 2015).

Although sharing expertise is an important facet of partnerships for development (see Draxler, 2008) and often expected from the private sector, it appears that the only partners involved in education projects for CGC are its vendors and suppliers. The interviewee emphasised that although the government is informed and an approval for intended projects is granted, the company's relationship with government with regards to educational projects cannot be called a 'partnership'. The principles of 'partnerships' require that partners share efforts, risks and benefits. The 
relationship described by the interviewee indicates an imbalanced or nonexistent partnership with government.

\section{Impact Assessment}

At commencement of CSR projects, needs analyses are presumably carried out to ascertain the needs of schools. Theoretically, when a needs analysis has been performed, one would expect that an evaluation or impact assessment will be conducted after the completion of the project. However, given the individual right to interpretation of phenomena, the word impact holds different meanings for different companies with regards to CSR initiatives. As witnessed in the Nigerian cases here, impact assessment appears to be largely quantitative and vaguely measured. In reference to its infrastructure projects, the CGC interviewee mentioned the fact that in the last five years, the company has 'impacted more than 50 schools'. An alternative measure adopted by Access Bank Plc is the reference to the number of students that may have benefitted from the initiatives, with instances indicating that over 150 students may have been impacted by building renovations carried out in the school (Access Bank Plc, 2009).

A different approach that appears to have been adopted by NFI indicates that project objectives may have been tied to global goals. The interviewee, who appeared to have previous experience in the development field, stated that:

[W] try to do a monitoring and evaluation to see the impact of the programmes that we do. So if MDG says 'we want to reduce this so-so-so by this percentage', so whatever area that we pick, that catchment area we do an assessment and say by how much has it reduced illiteracy; by how much has it reduced poverty. Like some of our students from the football team have made national team; some of them have gotten scholarship to study in the United States, just because they could play football. And that, as you can see, has reduced level of poverty and illiteracy, not only for the student but also for the family. (NFI interview, 2015)

The interviewee also pointed out:

We get an independent body to do the assessment for us because we want to. . . they do a before-survey, then it's an annual thing, after each year, when we finish up with a project, they would evaluate it. To see the key objectives that we want to achieve, have we achieved them, how does that help the target audience. (NFI interview, 2015)

Overall, dealing with infrastructural development may be a safe option because the companies can easily list how many projects have been completed and the number of students likely to benefit from the additional 
buildings, facilities, books or equipment. However, the actual impact is unknown for these initiatives on access and quality of education or even on other development indices that may be related to education.

\section{CSR PRACTICES IN NIGERIA-IMPLICATIONS AND LIMITATIONS}

\section{Role of Government}

Evidence suggests that NFI and CGC are not currently engaged in the direct provision of education, particularly at the basic education level. Although most CSR initiatives have been within public schools, contributions have been mostly financial, thus reserving service delivery for the government. This position may not seem to undermine the government's position as the main provider of education but highlights its resource gap, especially with respect to capital expenditures, an area which appears to be the delight of the companies.

The closest instance to engagement in direct provision of education is the Dangote Academy, a vocational training academy established in 2010 and operated by the Dangote Group, which does not only appear to plug the gap in supply of graduates for the relevant manufacturing sector but also highlights the lack of institutional capacity by the government to run a quality vocational education system that can serve the needs of relevant employers of labour (https://dangote.com/careers/academy/). Dangote Academy runs graduate engineer, junior technician and vocational training schemes. Delivery of basic education, therefore, appears to remain within the direct control of governments, albeit, there are signs that the government may be conceding its role in infrastructural development of schools to the corporate sector.

\section{Fragmentation of Activities}

CSR activities in education are run with little or no collaboration with other actors - corporate or government. Even claims of partnerships are not clearly defined, are unbalanced and are more or less superficial. Evidence from this study suggests that the companies are not collaborating with other companies on CSR activities within the education arena but are willing to enter into contracts with organisations with the technical capacity in education, such as the British Council. Also, in presumed PPPs surrounding infrastructural development, it appears that the company may bring the funds and hire the building experts with little or no contribution on the part 
of the government. Engagement with government is perceived more as an 'approval process' - a mundane task that must be performed. Then again, working independently serves business interests better than collaboration with visibility for branding and reputation building. The impact of this is that initiatives are fragmented and therefore may not be effective.

\section{Deepening Disparities}

There are indications that CSR practices may further widen regional gaps in educational development. Most of the businesses reviewed have offices, either regional or headquarters, in Lagos (the commercial centre of Nigeria), in addition to other offices in other major urban centres such as Abuja and Port Harcourt. Therefore, given the concept of 'social responsibility within communities where a company operates', these urban areas are prime recipients of their CSR endeavours. Apart from manufacturing and consumer good companies that may have industrial plants in rural areas and, therefore, perform CSR in the communities around them, other sectors, particularly the service industry, that are urban-based concentrate their activities in urban areas.

\section{CONCLUSION}

This study has investigated corporate philanthropy as practised by indigenous Nigerian companies through CSR initiatives in education in comparison to companies with higher proportions of foreign ownership. Education is as important to MNCs/TNCs as it is to local companies operating within developing countries. Despite this, little attention has been paid to CSR contributions by indigenous firms. This study set out to explore the contributions of Nigerian companies to the education sector, undertaken through CSR initiatives.

The findings of this study reveal that the major form of CSR contribution to education by Nigerian companies is financial resources, with little to no engagement in the direct provision of education through a contractual arrangement. The area that has received more attention has been infrastructural development of learning environments. There are no indications of contribution of innovative interventions, such as witnessed from ICT companies ${ }^{2}$ elsewhere, and also no evidence of attempts to

2 One example is the Jordan Education Initiative (JEI) in which Cisco Systems and Microsoft not only developed software and hardware components for the project but also provided learning approaches and ICT curriculum. 
directly or indirectly influence policies on learning processes such as curriculum design.

Overall, CSR contributions studied here are largely uncoordinated and fragmented, a finding earlier presented by van Fleet (2012). This is the result of companies working without collaboration with other actors, including the government. Although some studies have shown corporate sector engagements in networks of governance (see Ball, 2008), this study suggests that given the lack of relevant expertise and the penchant to operate independent of government and other actors, Nigerian companies feature more within the financing-only arena of corporate participation in education.

There is an ongoing debate on whether there is a dichotomy between social and economic objectives (Draxler, 2012; Porter \& Kramer, 2002); however, the fact remains that companies exist within society and their survival is dependent on the state of the environment where they operate. Therefore, failure in the social system is bound to affect them. Although, the companies profess that the CSR initiatives undertaken are more philanthropic with the aim of addressing a 'need', findings reveal that these philanthropic engagements are laced with business interests. In the short run, the business expects to improve company reputation and brand recognition while strengthening community relationships. For long-term benefits of investing in education, the companies look forward to improving their competitive context by investing in future markets (customers/ clientele) and workforce development. These motivations are generally in contrast with the traditional views on provision of social services.

The place of the corporate sector within the development arena is growing, hence there is the need to identify what implications it poses for the traditional structure. There are indications that with increasing participation of the corporate sector in education, confidence in the capacity of government is slowly eroding. Also, a culture of dependence is growing with schools and communities looking to companies as the best alternatives to government support. Presently, some consolation exists in the fact that the companies are yet to venture into direct provision of public education. The initiatives of the companies also appear to be reinforcing age-long regional disparities in education across the country-further deepening the rural-urban divide and the marginalisation of the less-privileged. The implication of this, that the most marginalised are still being left out of the education process, corroborates van Fleet's findings (2012). Finally, the uncoordinated and fragmented nature of contributions has prevented the education sector priorities from being addressed.

Further work in this field may need to address the magnitude of contributions by local companies in developing countries and how these 
contributions may be influencing educational outcomes. A survey will take the findings of this study further by investigating the capacity of the companies, the proportion of the CSR budget that may be allocated to educational initiatives and the way these may be harnessed to aid the achievement of global goals, taking into consideration the potential impact on the role of government. Additionally, it would be interesting to explore deeper the potential influence of the corporate sector in educational policies at regional and national levels.

\section{REFERENCES}

Access Bank Plc. (2009). Corporate social responsibility report. Lagos, Nigeria: Author. Retrieved June 29, 2015, from https://www.accessbankplc.com/AccessBankGroup/ media/Documents/Sustainable\%20Reports/CSR_report_2009.pdf

AfDB, OECD, \& UNDP. (2014). African economic outlook: Global value chains and Africa's industrialisation. Paris, France: OECD Publishing.

Akpan, W. (2006). Between responsibility and rhetoric: some consequences of CSR practice in Nigeria's oil province. Development Southern Africa, 23(2), 223-240.

Amaeshi, K., Adi, B., Ogbechie, C., \& Amao, O. (2006). Corporate Social Responsibility (CSR) in Nigeria: western mimicry or indigenous practices? (International Centre for Corporate Social Responsibility Research Paper Series). Nottingham, UK: International Centre for Corporate Social Responsibility, Nottingham University.

Ball, S. J. (2008). New philanthropy, new networks and new governance in education. Political Studies, 56(4), 747-765.

Bhanji, Z. (2008). Transnational corporations in education: filling the governance gap through new social norms and market multilateralism? Globalisation, Societies and Education, 6(1), 55-73.

Bhanji, Z. (2012). Microsoft Corporation: a case study of corporate-led PPPs in education. In S. Robertson, K. Mundy, A. Verger, \& F. Menashy (Eds.), Public private partnerships in education: new actors and modes of governance in a globalizing world (pp. 182-200). Cheltenham, UK and Northampton, MA, USA: Edward Elgar Publishing.

Bradesco Bank. (2014). Supplementary information - Third quarter 2012. São Paulo, Brazil: Author.

British Broadcasting Corporation. (2012). Nigerians living in poverty rise to nearly 61\%. Retrieved September 10, 2017, from https://www.bbc.com/news/ world-africa-17015873

Burnett, N., \& Bermingham, D. (2010). Innovative financing for education. Paper presented at the UNESCO Future Seminar, Paris, France.

Carroll, A. B. (1979). A three-dimensional conceptual model of corporate performance. Academy of Management Review, 4(4), 497-505.

Carroll, A. B. (1991). The pyramid of corporate social responsibility: toward the moral management of organizational stakeholders. Business Horizons, 34(4), $39-48$.

Carroll, A. B., \& Shabana, K. M. (2010). The business case for corporate social 
responsibility: a review of concepts, research and practice. International Journal of Management Reviews, 12(1), 85-105.

Colvin, R. L. (2005). The new philanthropists: Can their millions enhance learning? Education Next, 5(4), 34-41.

Deutsche Gesellschaft für Technische Zusammenarbeit. (2009). Corporate Social Responsibility in sub-Saharan Africa: A survey on promoting and hindering factors. Eschborn, Germany: Author.

Draxler, A. (2008). New partnerships for EFA: Building on experience. Paris, France: UNESO-IIEP. Retrieved February 21, 2015, from http://files.eric.ed.gov/ fulltext/ED499733.pdf

Draxler, A. (2012). International PPPs in education: New potential or privatizing public goods? In S. Robertson, K. Mundy, A. Verger, \& F. Menashy (Eds.), Public private partnerships in education: New actors and modes of governance in a globalizing world (pp.43-62). Cheltenham, UK and Northampton, MA, USA: Edward Elgar Publishing.

Federal Republic of Nigeria. (2004). National policy on education. Lagos, Nigeria: NERDC Press.

Federal Republic of Nigeria. (2013). National policy on education. Lagos, Nigeria: NERDC Press.

Garriga, E., \& Melé, D. (2004). Corporate social responsibility theories: mapping the territory. Journal of Business Ethics, 53(1-2), 51-71.

Genevois, I. (2010). Innovative financing: The case of public private partnerships in education. Paper presented at the UNESCO Future Seminar, Paris, France.

Global Business Coalition for Education (2014). Membership. Retrieved December 12, 2014, from http://gbc-education.org/

Husted, B. W., \& Allen, D. B. (2006). Corporate social responsibility in the multinational enterprise: strategic and institutional approaches. Journal of International Business Studies, 37(6), 838-849.

Jupp, V. (2006). The Sage dictionary of social research methods. London, UK: Sage Publications.

Kaarbo, J., \& Beasley, R. K. (1999). A practical guide to the comparative case study method in political psychology. Political Psychology, 20(2), 369-391.

LaRocque, N. (2008). Public-private partnerships in basic education: An international review. Reading, UK: CfBT Education Trust.

Matten, D., \& Moon, J. (2008). 'Implicit' and 'explicit' CSR: a conceptual framework for a comparative understanding of corporate social responsibility. Academy of Management Review, 33(2), 404-424.

Oando Foundation. (2014). Oando Foundation. Retrieved December 12, 2014, from http://www.oandofoundation.org/

Oando Plc. (2013). Sustainability report 2013. Lagos, Nigeria, Author. Retrieved March 30, 2015, from https://www.oandoplc.com/sustainability/

Obalola, M. (2008). Beyond philanthropy: corporate social responsibility in the Nigerian insurance industry. Social Responsibility Journal, 4(4), 538-548.

Organisation for Economic Co-Operation and Development. (2003). Philanthropic foundations and development co-operation, Off-print of the DAC Journal 2003, $4(3)$.

Patrinos, H. A., Osorio, F. B., \& Guáqueta, J. (2009). The role and impact of publicprivate partnerships in education. Washington, DC: World Bank Publications.

Porter, M. E., \& Kramer, M. R. (2002). The competitive advantage of corporate philanthropy. Harvard Business Review, 80(12), 56-68. 
Ravitch, S., \& Riggan, M. (2012). Reason and rigor: How conceptual frameworks guide research. Thousand Oaks, CA: Sage Publications.

Samoff, J., \& Carrol, B. (2013). Education for all in Africa: not catching up, but setting the pace. In R. F. Arnove, C. A. Torres, \& S. Franz (Eds.), Comparative education: The dialectic of the global and the local (4th ed., pp.403-443). Lanham, MD: Rowman \& Littlefield Publishers.

Srivastava, P., \& Oh, S.-A. (2010). Private foundations, philanthropy, and partnership in education and development: mapping the terrain. International Journal of Educational Development, 30(5), 460-471.

Sulek, M. (2010). On the modern meaning of philanthropy. Nonprofit and Voluntary Sector Quarterly, 39(2), 193-212.

UNESCO. (2014). EFA global monitoring report 2013/4. Teaching and learning: Achieving quality for all (1st ed.). Paris, France: Author.

Valor, C. (2007). A global strategic plan for corporate philanthropy. Corporate Communications: An International Journal, 12(3), 280-297.

van Fleet, J. (2012). A disconnect between motivations and education needs: why American corporate philanthropy alone will not educate the most marginalized. In S. Robertson, K. Mundy, A. Verger, \& F. Menashy (Eds.), Public private partnerships in education: New actors and modes of governance in a globalizing world (pp.158-181). Cheltenham, UK and Northampton, MA: Edward Elgar Publishing.

World Bank. (2008). Nigeria: A review of the costs and financing of public education. Washington, DC: Author.

Yin, R. K. (1994). Case study research: Design and methods (2nd ed.). Thousand Oaks, CA: Sage Publications. 